\title{
Effect of Compaction during Casting on Anisotropic Compressive Strength of Baked Clay
}

\author{
Muhammad Auchar ZARDARI, Nawab Ali LAKHO
}

\begin{abstract}
Due to high cost of aggregates and cement in plains of Pakistan, there is an overwhelming need to investigate structural properties of Reinforced Baked Clay (RBC) as a possible substitute of Reinforced Cement Concrete (RCC) for construction of low cost houses. In this paper, direction dependent cube crushing strength of baked clay is investigated. For this purpose, baked clay beams were cast by applying compactive pressure of intensity from 0 to $7 \mathrm{MPa}$. The clay beams were fired at a temperature of $1000^{\circ} \mathrm{C}$. Cubes were cut from these baked clay beams. The cubes were tested for compressive strength in directions, i.e., parallel and perpendicular to casting layers. Anisotropy was observed in compressive strength of baked clay cubes. The baked clay showed anisotropic behaviour in compressive strength in general. However, the anisotropy in compressive strength was decreased by increasing compactive pressure at the time of casting of clay beams. Average crushing strength of baked clay cubes tested in a direction parallel to casting layers was found to be $35 \mathrm{MPa}$, and that of perpendicular to casting layers was $30 \mathrm{MPa}$. The magnitude of compressive strength of baked clay is 1.5 times higher than that of normal concrete.
\end{abstract}

Keywords: anisotropic compression behaviour; casting layers; compressive strength; construction material; fired clay

\section{INTRODUCTION}

The per capita income of Pakistan in 2015 was about 1513 United States dollars. This income is not sufficient for common people to purchase one's own house in addition to meet food and other requirements necessary for life. In plains of Pakistan, there is shortage of aggregates. For construction of a building, the aggregates are usually transported from a far distance. Thus, high transportation charges are to be paid. To reduce the cost of construction of a residential building, it is proposed to replace Reinforced Cement Concrete (RCC) with Reinforced Baked Clay (RBC). The arguments in support of RBC as an economical building material are: clay is locally available in huge quantity, clay can be quarried easily at a shallow depth requiring less labour cost, the local people are well aware of the quarrying, casting, firing and construction activities using clay, baked clay is durable material of construction, the houses constructed with baked clay stay cool during summer and hot during winter, baked clay is strong against decay and attack of termites.

Fired and unfired clay bricks have been used in buildings since thousands of years [1-4]. Arched roofs of storage rooms constructed using unbaked clay bricks about 3000 years ago, still exist in Egypt. Walls of the buildings of Moen-Jo-Daro in Sindh, Pakistan, constructed with baked clay bricks as old as 5000 years, are also standing without significant disintegration and weathering. This implies that the buildings constructed with baked clay bricks can be designed to last for thousands of years.

In design of structural members (e.g., beams and columns) of a building, compressive strength of a construction material plays a significant role. In this regard, vast literature is available for compressive strength of concrete, see, e.g. references [5-15]. The research suggests that concrete is anisotropic in compressive strength. In general, compressive strength of concrete specimen tested in a direction parallel to casting layers is more than that tested in a direction perpendicular to casting layers [16].

As mentioned earlier, it is a new concept to propose $\mathrm{RBC}$ as a low-cost construction material to replace RCC. In this regard, it is important to investigate whether baked clay shows anisotropic behaviour of compressive strength when tested in different directions with respect to casting layers. This knowledge of direction dependent compression behaviour of baked clay is important for design of beams and columns of a building. No study is reported regarding anisotropic compression behaviour of baked clay [17-21]. This study investigates the effect of casting layers on compressive strength of baked clay.

\section{MATERIALS AND METHODS \\ 2.1 Mixture of Clay and Pit Sand}

Clay was quarried locally at a depth of $1 \mathrm{~m}$. The clay obtained at this depth was free from organic matter and aggregates. If clay is mixed with organic matter, more shrinkage may occur during drying. In addition, splitting of clay specimen may occur in firing process due to expansion of aggregates. The clay obtained from the quarry was in the form of lumps (Fig. 1). Therefore, clay was ground mechanically by utilizing Pulverizer to make it in the powdered form. Seventy percent of clay and thirty percent of pit sand, by weight, were thoroughly mixed. Pit sand was excavated near the vicinity of River Indus close to Nawabshah city.

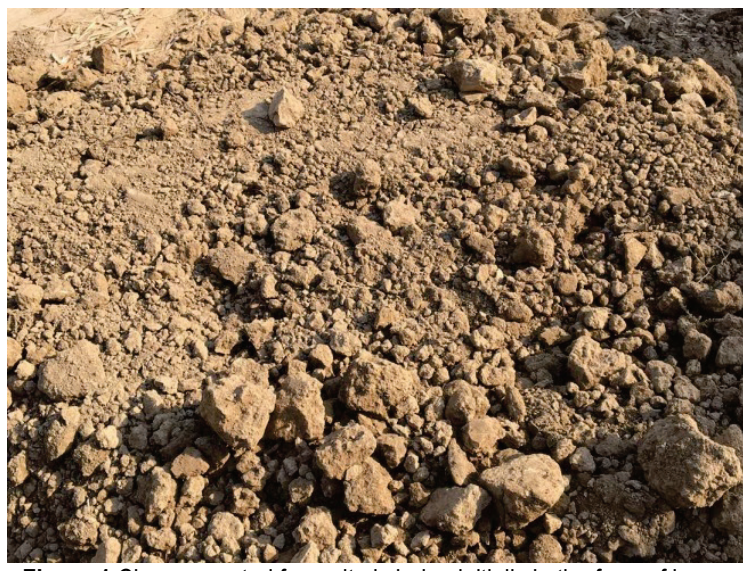

Figure 1 Clay excavated from site is being initially in the form of lumps

The clay-pit-sand mixture was mixed with $22 \%$ of potable water, by weight, in a mechanical mixer for fifteen minutes to achieve proper workability. The proportions of 
clay and pit sand in a ratio of 70:30 were selected based on results of a previous study [18] with an objective to reduce drying shrinkage and increase compressive strength of the mixture. Standard proctor compaction tests were carried out on mixture of $70 \%$ clay and $30 \%$ pit sand, by weight. The value of optimum moisture content to achieve maximum dry density of the moist mixture of clay and pit was calculated to be $12.5 \%$. For convenience, the earth beams cast with the mixture of $70 \%$ clay and $30 \%$ sand will be referred to as clay beams in this paper.

It is to be noted that this type of study involves moulding of clay beams. For proper moulding of clay beams without cracking and breaking at the time of casting, it is very necessary that the moisture content of the mixture of clay and pit sand should be as high as its magnitude of plastic limit. The plastic limit of the clay was determined as $22 \%$. Therefore, the water in the mixture of clay and pit sand was increased to $22 \%$ instead of optimum moisture content of $12.5 \%$. The problem of easy moulding and workability was resolved by addition of more water up to $22 \%$. On the other hand, the more the percentage of water in clay is present, the larger will be drying time and the higher the rate of shrinkage. Therefore, it is necessary to drain out extra water added above optimum moisture content of the clay and pit sand mixture.

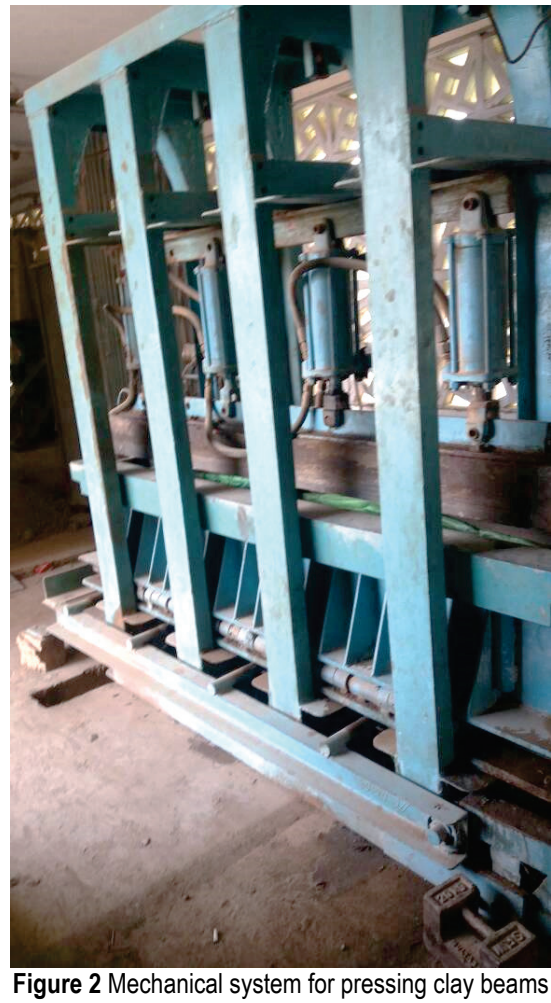

Clay beams of dimensions $0.165 \times 0.33 \times 2 \mathrm{~m}$ were cast in a steel mould. Moist clay-pit sand mixture was put in layers in the mould. The beams were covered with porous propylene fabric sheet. Wooden plunger of the Mechanized System was utilized to apply compactive pressure on the clay beams (Fig. 2). The compactive pressure applied was $0,1,2,3,4,5,6$, and $7 \mathrm{MPa}$. The compactive pressure was gradually increased with an intension to investigate its effect on compressive strength of baked clay when tested in directions parallel and perpendicular to the casting layers. Each increment of compactive pressure on the clay beams was maintained for 24 hours in drained condition. Due to application of the load, water present in the moist mixture of clay and pit sand dripped out from the beams. The drainage of the added water in the clay beams facilitated compaction process. Thus, the clay beams got densified and their density increased. Due to drainage of the water, the moisture content of the clay beams was decreased up to optimum moisture content (i.e., 12\%). The drainage of water from the beams due to application of load was necessary to obtain maximum dry density and to reduce shrinkage of the clay beams on drying. After de-moulding of the beams from the Mechanized System, the beams were covered with plastic sheet and were placed in a ventilated hall. After drying in shade, the clay beams were transported with the help of platform lift (Fig. 3) in a kiln (Fig. 4) at a temperature of $1000{ }^{\circ} \mathrm{C}$. Cubes of $0.15 \mathrm{~m}$ size were sawed from baked clay beams using cutter machine.
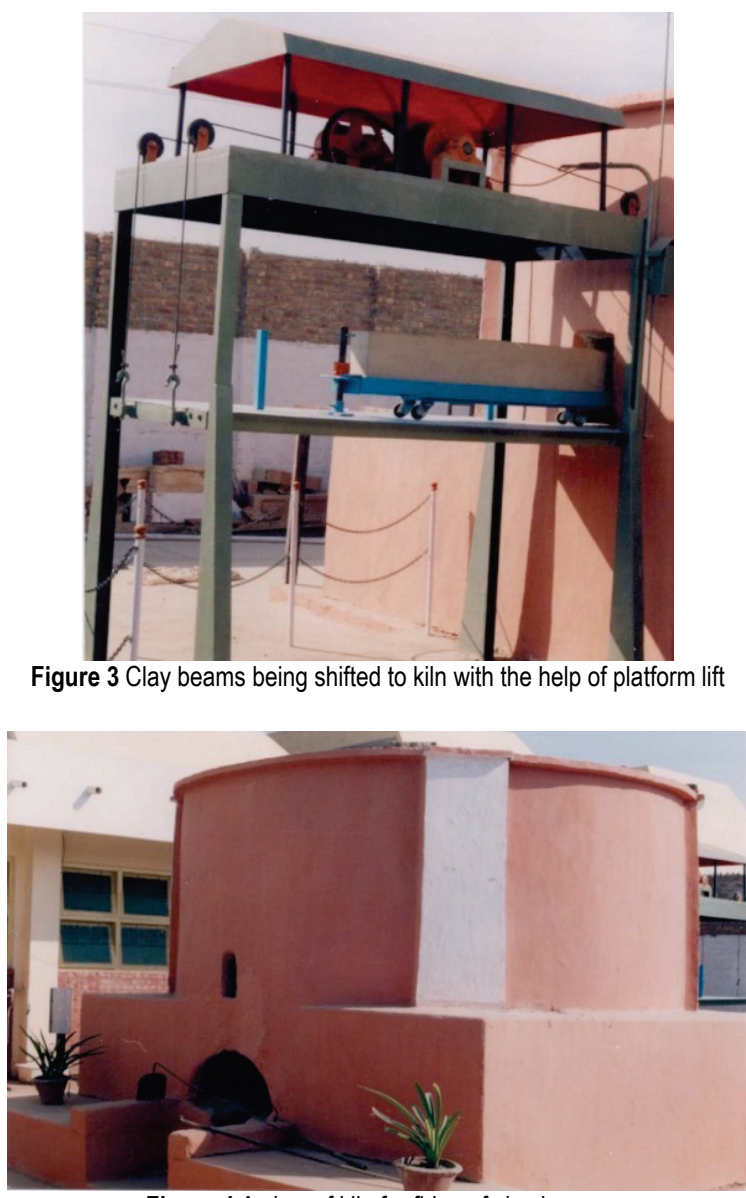

Figure $4 \mathrm{~A}$ view of kiln for firing of clay beams

\subsection{Testing Procedure}

It is already mentioned that the clay beams were cast in layers placed one over the others. The focus of this study is to investigate the compressive strength of fired clay cubes when tested in directions: parallel and perpendicular to the casting layers (Fig. 5). The fired clay cubes were tested for compressive strength in Forney's Universal Testing Machine (Fig. 6).

The compressive strength of fired clay cubes was tested in accordance with BS EN 12390-3 [22] and density of fired clay was determined as per ASTM C642-13 [23]. 


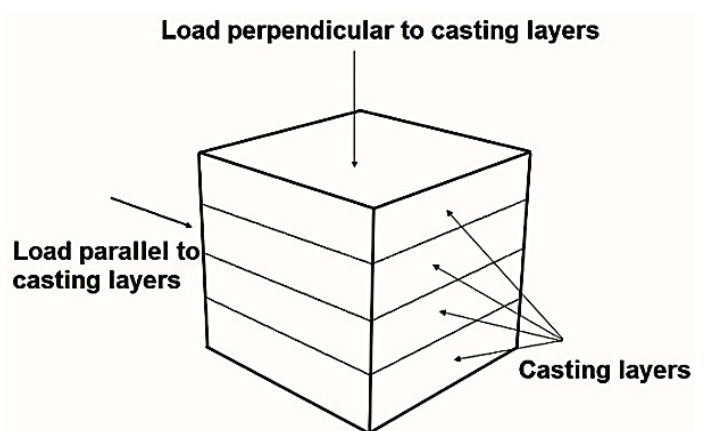

Figure 5 Directions in which compressive load was applied to baked clay cubes with respect to casting layers.

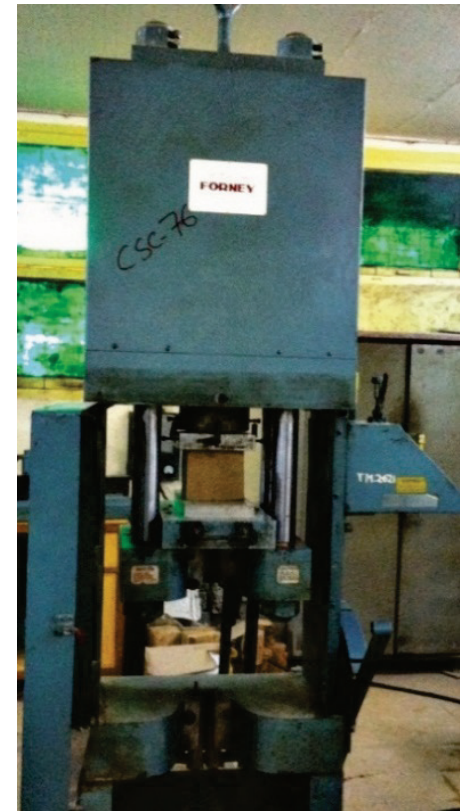

Figure 6 Fired clay cubes are tested in Forney's Universal Testing Machine

\section{RESULTS AND DISCUSSION \\ 3.1 Density of Baked Clay}

The density of baked clay was found to be about 1920 $\mathrm{kg} / \mathrm{m}^{3}$. Comparison with density of normal concrete (i.e., $2400 \mathrm{~kg} / \mathrm{m}^{3}$ ) reveals that baked clay is $20 \%$ lighter than normal concrete. It is to be noted that light weight material is generally preferred to heavy weight material in construction of buildings.

\subsection{Compressive Strength of Fired Clay Cubes}

Compressive strength of fired clay cubes was determined with the help of Forney's Universal Testing Machine. The compressive strength of fired clay cubes sawed from beams that were compacted at varying pressure intensity from 0 to $7 \mathrm{MPa}$ is presented in Fig. 7. The compressive strength of fired clay cubes was determined for loading directions that were parallel and perpendicular to the casting layers. As expected, the anisotropy in compressive strength of baked clay decreased with increase in intensity of compactive pressure that was applied during casting. Up to compactive pressure of 0 to $2 \mathrm{MPa}$, the compressive strength of baked clay tested in perpendicular direction was $75 \%$ of that obtained in direction parallel to casting layers. As the compactive pressure was increased from 2 to $7 \mathrm{MPa}$, the cube crushing strength of fired clay loaded in perpendicular direction to casting layers was about $86 \%$ of that when loaded parallel to casting layers.

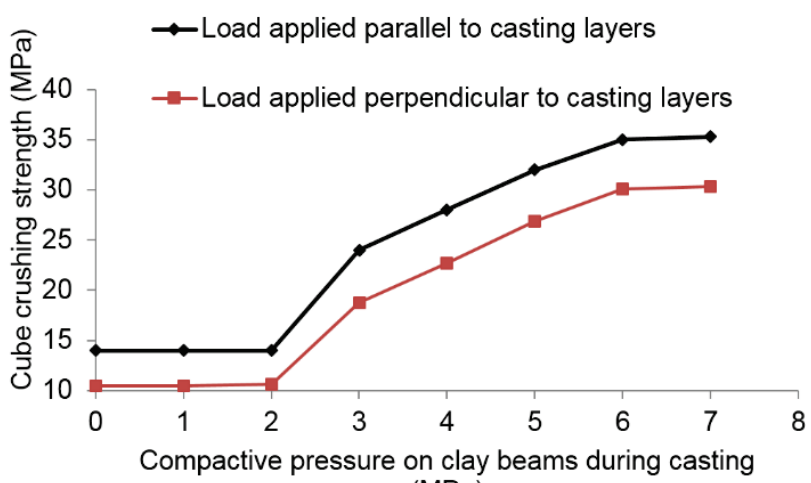

(MPa)

Figure 7 Compressive strength of fired clay when loaded in direction parallel, and perpendicular to casting layers

At low compacting pressure of 0 to $2 \mathrm{MPa}$, the compactive load was mainly carried by water present in clay beams. As the beams were placed in shade for drying, the moisture in the beams got slowly evaporated resulting in more voids. Thus, the fired clay cubes showed relatively more anisotropy in compressive strength. On the other hand, when the compactive pressure was increased above $2 \mathrm{MPa}$, the added water present in the clay beams started to drain out. Due to drainage of water, compactive load was gradually transferred to soil causing decrease in voids. Thus, the soil became denser and the compressive strength of fired clay cubes relatively improved leading towards closer to isotropic behavior.

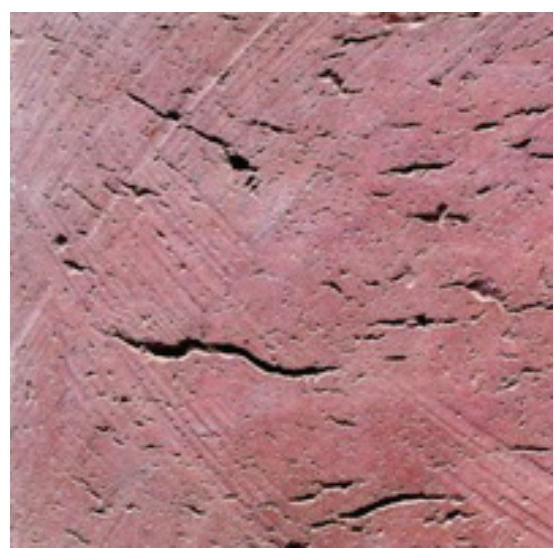

Figure 8 Internal cracks in a cube cut in a section perpendicular to casting layers

The compressive strength of the baked clay cubes tested in the direction perpendicular to the casting layers was about $86 \%$ of those tested parallel to the casting layers. Average compressive strength of the baked clay cubes was found to be $35 \mathrm{MPa}$, and $30 \mathrm{MPa}$ when tested in the directions (i) parallel and (ii) perpendicular to the casting layers, respectively. The anisotropic compression behaviour of baked clay can be attributed to size, shape and orientation of the internal cracks that were observed after cutting the cubes from the beams in a section parallel and perpendicular to the casting layers (Figs. 8 and 9). There were several irregular cracks of different width and length on the sawed surface of the cubes. It was further observed that these cracks were of two types. Some of these cracks 
were very small voids measuring less than the fraction of 1 $\mathrm{mm}$ in diameter. These voids may have been caused due to evaporation of entrapped moisture. The other cracks were like semi-circular plate-like voids oriented nearly parallel to casting layers. These cracks were about 0.0001 to 0.001 $\mathrm{m}$ wide and 0.0001 to $0.01 \mathrm{~m}$ in diameter. These cracks were developed during the process of drying and shrinkage. After the surface of the beams was dried, uniform shrinkage of the beams stopped. Upper surface of the clay beam became solid shell around moist mass of clay in the centre of beam. In this condition, further shrinkage occurred in the interior of the clay beams. This shrinkage was the likely cause of cracks in the interior of the beams that were semi dried.

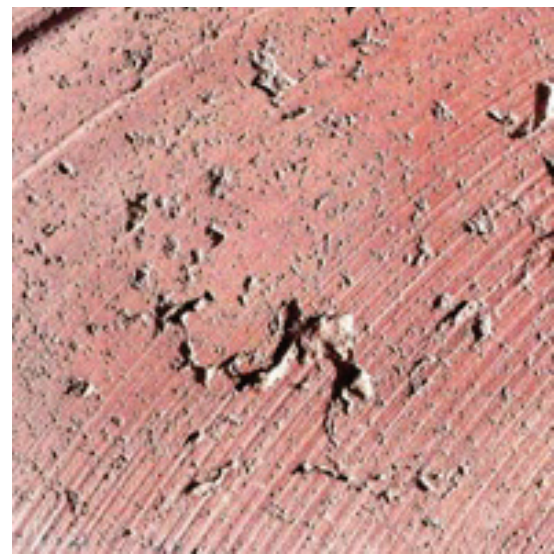

Figure 9 Internal cracks in a cube cut in a section parallel to the casting layers

A section of a beam cut parallel to the casting layers is shown in Fig. 9. In this section, the voids are cut horizontally throughout length which is larger than width. Thus, effective area of the section was decreased as compared to that of the section cut perpendicular to the casting layers. This implies that, when the load was applied perpendicular to the casting layers, less effective area of the section was there to resist the load and the cubes showed lower value of the crushing strength.

\subsection{Discussion}

Beams in a building may be subjected to compressive forces and bending stresses during service life. The bending force acts in a direction perpendicular to the casting layers. Thus, resultant compressive force develops in a direction parallel to the casting layers. It is possible to cast baked clay columns using the Mechanized System in a similar way as the baked clay beams were cast. In case of a column, both the compressive forces and bending stresses are applied parallel to the casting layers. It is to be noted that the compressive strength of baked clay cubes was relatively higher when the load was applied in the direction parallel to the casting layers. This implies that maximum cube crushing strength of baked clay cast and compacted in the way discussed in this paper can be utilized in beams and columns of a building.

The compressive strength of normal concrete is 20 $\mathrm{MPa}$. The results presented in this study suggest that the compressive strength of baked clay is 1.5 times higher than that of normal concrete.

\section{CONCLUSIONS}

Cubes were sawed from baked clay beams and were tested for compressive strength in directions $(i)$ parallel and (ii) perpendicular to the casting layers. The following conclusions were made.

1) Baked clay showed anisotropic compression behaviour.

2) Anisotropy of baked clay decreased with increase of compactive pressure that was applied during casting of clay beams.

3) Compressive strength of baked clay cubes in a direction perpendicular to the casting layers was found to be about $86 \%$ of that obtained in a direction parallel to the casting layers.

4) Average compressive strength of the baked clay cubes was found to be $30 \mathrm{MPa}$, and $35 \mathrm{MPa}$ in directions perpendicular and parallel to the casting layers, respectively.

5) This study suggests that maximum compressive strength in a direction parallel to casting layers of baked clay could be effectively utilized in structural members of a building. This is because the resultant compressive load on a beam and column acts in a direction parallel to the layers in which baked clay beams are cast.

\section{REFERENCES}

[1] Adam, J. P. (2005). Roman Building: Materials and Techniques. Routledge, London.

[2] Baizerman, M. (2012). Dawn and Sunset: Insight into the Mystery of the Early Mesopotamian Civilization. Strategic Book Publishing, Houston.

[3] Gates, C. (2011). Ancient Cities: The Archaeology of Urban Life in the Ancient near East and Egypt, Greece and Rome. Routledge, London. https://doi.org/10.4324/9780203830574

[4] Mcintosh, J. R. (2005). Ancient Mesopotamia: New Perspectives. ABC-CLIO, Inc., California.

[5] Sinaie, S., Heidarpour, A., Zhao, X. L., \& Sanjayan, J. G. (2015). Effect of size on the response of cylindrical concrete samples under cyclic loading. Construction and Building Materials, 84, 399-408. https://doi.org/10.1016/j.conbuildmat.2015.03.076

[6] Sim, J. I., Yang, K. H., Kim, H. Y, \& Choi, B. J. (2013). Size and shape effects on compressive strength of lightweight concrete. Construction and Building Materials, 38, 854-864. https://doi.org/10.1016/j.conbuildmat.2012.09.073

[7] Aslani, F. (2013). Effects of specimen size and shape on compressive and tensile strengths of self-compacting concrete with or without fibers. Magazine of Concrete, 65(15), 914-929. https://doi.org/10.1680/macr.13.00016

[8] Del Viso, J. R., Carmona, J. R., \& Ruiz, G. (2008). Shape and size effects on the compressive strength of high-strength concrete. Cement and Concrete Research, 38(3), 386-395. https://doi.org/10.1016/j.cemconres.2007.09.020

[9] Yi, S. T., Yang, E. I., \& Choi, J. C. (2006). Effect of specimen sizes, specimen shapes, and placement directions on compressive strength of concrete. Nuclear Engineering and Design, 236(2), 115-127. https://doi.org/10.1016/j.nucengdes.2005.08.004

[10] Ros, P. S., Yazzar, S. A., \& Calvo, A. C. (2003). Influence of confinement on high strength concrete behaviour. Materials and Structures, 36(7), 439-447. https://doi.org/10.1007/BF02481523 
[11] Kumar, R. \& Bhattacharjee, B. (2003). Porosity, pore size distribution and in situ strength of concrete. Cement and Concrete Research, 33(1), 155-164. https://doi.org/10.1016/S0008-8846(02)00942-0

[12] Candappa, D. C., Sanjayan, J. G., \& Setunge, S. (2001) Complete triaxial stress-strain curves of high-strength concrete. Journal of Materials in Civil Engineering, 13(3), 209-215. https://doi.org/10.1061/(ASCE)0899-1561(2001)13:3(209)

[13] Toutanji, H. \& Bayasi, Z. (1998). Effects of manufacturing techniques on the flexural behavior of steel fiber-reinforced concrete. Cement and Concrete Research, 28(1), 115-124. https://doi.org/10.1016/S0008-8846(97)00213-5

[14] Tokyay, M. \& M. Özdemir. (1997). Specimen shape and size effect on the compressive strength of higher strength concrete. Cement and Concrete Research, 27(8), 1281-1289. https://doi.org/10.1016/S0008-8846(97)00104-X

[15] Chin, M. S., Mansur, M. A., \& Wee, T. H. (1997). Effects of shape, size, and casting direction of specimens on stressstrain curves of high-strength concrete. ACI Materials Journal, 94(3), 209-219.

[16] Leshchinsky, A. (1990). Anisotropy of Concrete Strength. Cement, Concrete and Aggregates, 12(2), 117-119. https://doi.org/10.1520/CCA10280J

[17] Ansari, A. A. \& Lakho, N. A. (2013). Determination of Structural Properties of Baked Clay as Replacement of RCC. International Journal of Emerging Technology and Advanced Engineering, 3(2), 17-25.

[18] Ansari, A. A. (2008). Experimental Study of the Behaviour of Pre-Perforated Post-Reinforced Baked Clay Panels of Beams. PhD Thesis, Department of Civil Engineering, Quaid-e-Awam University of Engineering Science and Technology, Nawabsha.

[19] Ansari, A. A., Bhatti, N. K., \& Bhutto, A. (2013). Suitability of Pre-Perforated Post-Reinforced Baked Clay Beam Panels for Low Cost Housing. American Journal of Civil Engineering, 1(1), 6-15. https://doi.org/10.11648/j.ajce.20130101.12

[20] Lakho, N. A, Zardari, M. A., Memon, M., \& Saand, A. (2015). Design and fabrication of a mechanized system for casting and compacting laboratory size clay beams. Scientia Iranica, 22(6), 2046-2051.

[21] Lakho, N. A. \& Zardari, M. A. (2016). Comparison of Compressive and Tensile Strength of Baked Clay with Those of Normal Concrete. Engineering, 8, 301-307. https://doi.org/10.4236/eng.2016.86027

[22] BS EN 12390-3:2002. Testing hardened concrete - Part 3 Compressive strength of test specimens.

[23] ASTM C642-13:2013. Standard Test Method for Density, Absorption, and Voids in Hardened Concrete, ASTM International, West Conshohocken, PA.

\section{Contact information:}

Muhammad Auchar ZARDARI, PhD, Assistant Professor

Department of Civil Engineering,

Quaid-e-Awam University of Engineering, Science and Technology,

Nawabshah, 67480, Sindh, Pakistan

E-mail: muhammad.auchar@quest.edu.pk

Nawab Ali LAKHO, PhD, Assistant Professor

Department of Civil Engineering,

Quaid-e-Awam University of Engineering, Science and Technology,

Nawabshah, 67480, Sindh, Pakistan

E-mail: nawablakho@gmail.com 